MANTHAN: Journal of Commerce and Management

Volume 4, Issue 2, July-December 2017, pp. 82-92

doi: 10.17492/manthan.v4i02.11459

\title{
Saving Preferences and Financial Literacy of Self Help Group Members: A Study of Uttar Pradesh
}

\author{
Sandhya Ruhela* and Ajai Prakash**
}

\begin{abstract}
Microfinance is the provision of financial services to the rural and underprivileged sections of the society to engage in income-generating activities for their own growth and progress. This paper examines the income generating activities of Self-Help Groups (SHGs) for empowerment of women. It also analyses the saving preferences of SHG members and examines the financial literacy of these members after joining the SHGs. The analysis reveals that the different types of income generating activities started by SHG members include embroidery work, dairy, flower and bangle making, jute work, stitching work, vegetable cultivation and own shop. Among these, 'own shop' is the most prominent income generating activity followed by 'stitching work'. In terms of saving preference, 'own business development' is their first saving preference for sustainable livelihood; 'education of children' is their saving preference for future of their children and 'repairing of house' is their saving preference for immediate expenditure. The analysis in terms of financial literacy reveals that financial literacy of SHG members regarding ration card, voter card, bank account and their phone number has increased after joining of SHGs.
\end{abstract}

Keywords: Microfinance; Self Help Groups; Financial literacy; Empowerment.

\subsection{Introduction}

Microfinance is the provision of thrift, credit and other financial services and products of very small amounts to the poor for enabling them to raise their income levels and improve their living standards (www.rbi.org).Microcredit is the basic tool through which microfinance operates and is widely believed to be an effective way of contributing to socio-economic development through the empowering of self-help group members with seed financial capital.

*Corresponding author; Research Scholar, Department of Business Administration, University of Lucknow, Lucknow, Uttar Pradesh, India. (Email id: ruhela.sandhya@gmail.com)

**Associate Professor, Department of Business Administration, University of Lucknow, Lucknow, Uttar Pradesh, India. (Email id: ajaiprakash1@gmail.com) 
In recent public debates, microfinance has been mentioned as an important instrument to combat extreme poverty. The common products that MFIs provide include credit, savings, insurance and payment services. Microfinance products and services broadly include; credit, savings, insurance, money transfer (i.e. remittances, payment systems). Twenty-eight members of the Consultative Group to Assist the Poor (CGAP) have defined a Vision for the future of microfinance: a world in which poor people everywhere enjoy permanent access to a wide range of financial services, delivered by different types of institutions through a variety of convenient mechanisms (CGAP, www.cgap.org/publications/cgap-annual-report-2004). SHG is a "small, economic, homogenous and affinity group of rural/urban poor, voluntarily formed to save and contribute to a common fund known as group corpus to lend money to the members as per group decision and for working together for social and economic upliftment of their families and community" (Tamil Nadu Corporation for Development of Women, available at: www.tnwomendevelopmentcorporation.org). The World Bank defines empowerment as "the process of increasing the capacity of individuals or groups to make choices and to transform those choices into desired actions and outcomes". Microfinance through self-help groups is a mode of providing finance to the poor women of the rural community for their development and progress; mainly for their empowerment.

\subsection{Literature Review}

Microfinance has played a very important role in the development of Uttar Pradesh by attaining its goals like increase in saving and borrowing patterns, alleviation of poverty, educational improvement, and employment generation and has played a very powerful role in the creation of awareness and empowerment(Maurya, 2014).With the help of SHGs, microfinance activities are successful in achieving their goals for selfemployment, women empowerment, income generation and poverty alleviation and are very beneficial for the socio-economic development of BPL families as well as lowincome families(Tehra,2014). SHGs are flexible but they have failed to maintain a work culture; so better coordination among borrowers is required from the voluntary organizations for increasing performance of SHGs(Sharma, 2011).Credit help by microfinance institutions to women helps them in establishing income-generating activities for well-being of the households and this innovative approach put emphasis on financial intermediation with self-sustainability of institutions who provides credit helps to the women (Kulshrestha, 2001).

SHGs have been involved in empowering poor women belonging to the bottom of pyramid. Exploitation of poor is not possible because they do not depend on 
moneylenders anymore. Microfinance develops saving habits among self-help group members and microfinance by SHG is a boon to poor women. The key motive for joining SHG by women is not only to get just credit, it in an empowerment process and saving mobilization (Rai, 15). Self-help groups empowered women by giving facilities like savings and credit, and also helping women attain employment by adopting personal skills(Borah, 2014). Members of SHG start their business with group savings and equally sharing responsibility and profit from the business (Sharma \& Roy, 2012). The concept of self-help group provides platform to women to get credit assistance on time for running a small business firm and to reduce the reasons of poverty and inequality. The concept of SHG serves the principle, 'by the women, of the women and for the women'(Kumar \& Kalva, 2014). SHGs are formed by rural people with the objective of improving their livelihoods through collective savings and investments in incomegenerating activities (Sandhu, 2013).

Microfinance has empowered women and designed products and channel, which are friendly and suitable to poor women (Keshava, 2014). SHGs are helpful in empowerment of women, conveying of financial training and discipline amongst poor for long term socioeconomic benefits(Kumar, 2012).Microfinance develops confidence, courage, skill development and empowerment among SHG members(Sarumathi \& Mohan, 2011).SHG are helpful in empowering women, making them financially viable, increasing saving habit among members for further investment for development(Devi $\&$ Narasaiah, 2017). Women have been confirmed to be superior savers, better loan repayers and form efficient groups, which meet on weekly basis and collect savings from the members and reduce the cost delivery of small loans. The main motivating factors behind their joining of SHGs are access of credit facilities and increasing their savings to meet future contingencies. With help of the SHGs, borrowers are becoming independent, economically empowered and creating new ventures (Banerjee, Sayed \& Abraham, 2016).SHGs activities increase status of family in society, build decision making capability among members, increase saving habit of members, and increase members' self-confidence and self-reliance ( Sharma\&Varma, 2008).SHGs are a cost efficient mode to help and meet up the social and emotional requirements of individuals and families dealing with trouble in living (Prakash, 2013).

Members of SHGs have experience changes in their lives, which have led to rural development and will go a long way in achieving inclusive growth in India (Mishra, 2017).SHGs engaged in constructing micro-enterprises in India normally need to be able to fulfil the needs of finance, training and skills development(Singh et al., 2011).After participation in SHGs, women are able to take decisions regarding their political and economic domain and help them realise their empowerment goals 
(Henriques, 2016).SHGs have been found successful in savings mobilisation and getting credit for economic needs of the members (Lokahande, 2015).Financial inclusion has led to a remarkable change in the financial environment of the world, changing much of the liability of the individual to supervise their future plan for their money and wellbeing (Narula, 2017).

The main objectives of this study are:

(i) To study the income-generating activities of SHG members for their empowerment;

(ii) To study the saving preferences of SHG members; and

(iii) To study the financial literacy of SHG members after joining of SHG.

\subsection{Research Methodology}

The present study is descriptive in nature. Descriptive research design is concerned with determination of the frequency with which something occurs or the relationship between variables. The study is based on both primary and secondary data. The primary data were collected with the help of a structured questionnaire from four districts of Uttar Pradesh, two from western Uttar Pradesh; Ghaziabad and Meerut and two from eastern Uttar Pradesh; Lucknow and Lakhimpur kheri. 404 respondents have been selected from these cities for the present study and different statistical tools have been used for analysing the results. Percentage, frequency and descriptive analysis have been used.

\subsection{Data Analysis and Interpretation}

The result of descriptive analysis indicated in Table 1 shows that out of 404 respondents, 204 respondents are living in rural area and remaining 200 respondents are living in urban areas. The age groups are of $<20,21-30,31-40,41-50$ and $>50$ class intervals and they are $1.0 \%, 21.3 \%, 44.8 \%, 27.5 \%$ \& $5.4 \%$ respectively. This shows the most of respondents from whom the responses are collected belong to the 31 to 40 age group. While the data is scattered in all age groups, it can be said that the data is dominant in 31-40 age group. In terms of the marital status of the respondents, $94.3 \%$ are married, $3.0 \%$ are separated and $2.7 \%$ are widows. With reference to the education of the respondents $38.1 \%$ are illiterate, $21.8 \%, 19.1 \%, 14.1 \%, 3.7 \%, 3.0 \%$ and $0.2 \%$ have studied up to $5^{\text {th }}$ class, up to $8^{\text {th }}$ class, up to $10^{\text {th }}$, up to $12^{\text {th }}$ class, up to graduation and up to post-graduation respectively. The analysis of SHG membership period shows that out of the total 404 respondents, $224(55.4 \%)$ respondents have SHG membership period of 3-6 years, $109(27 \%)$ have less than 3 years and $71(17.6 \%)$ have more than 6 years. 
Table 1: Demographic Profile of the Respondents

\begin{tabular}{|c|c|c|c|}
\hline Main variables & Sub categories of variables & Frequency & \%percentage \\
\hline \multirow[t]{5}{*}{ Age } & $<20$ & 4 & 1.0 \\
\hline & $21-30$ & 86 & 21.3 \\
\hline & $31-40$ & 181 & 44.8 \\
\hline & $41-50$ & 111 & 27.5 \\
\hline & $>50$ & 22 & 5.4 \\
\hline Total & & 404 & 100.0 \\
\hline \multirow[t]{3}{*}{ Marital status } & Married & 381 & 94.3 \\
\hline & Separated & 12 & 3.0 \\
\hline & Widow & 11 & 2.7 \\
\hline Total & & 404 & 100.0 \\
\hline \multirow[t]{2}{*}{ Type of family } & Nuclear & 186 & 46.0 \\
\hline & Joint & 218 & 54.0 \\
\hline Total & & 404 & 100.0 \\
\hline \multirow[t]{7}{*}{ Education } & Illiterate & 154 & 38.1 \\
\hline & Up to 5 class & 88 & 21.8 \\
\hline & Up to 8 class & 77 & 19.1 \\
\hline & Up to 10 class & 57 & 14.1 \\
\hline & Up to 12 class & 15 & 3.7 \\
\hline & Up to graduation & 12 & 3.0 \\
\hline & Up to post graduation & 1 & 0.2 \\
\hline \multirow[t]{3}{*}{$\begin{array}{l}\text { Period of } \\
\text { membership }\end{array}$} & $<3$ year & 109 & 27.0 \\
\hline & 3-6 year & 224 & 55.4 \\
\hline & $>6$ year & 71 & 17.6 \\
\hline Total & & 404 & 100.0 \\
\hline
\end{tabular}

\subsection{Interpretation}

The results of Table 2 show that the maximum respondents (98.5\%) have started their business by amount of loan after joining of SHGs and only 5\% respondents have not started any business by amount of loan after joining of SHGs. From Table3,it is found that all respondents started their businesses after getting loan. There are different types of business that have been started by the respondents like embroidery, dairy, flower and bangle making, jute work, stitching work, vegetable cultivation, own shop and any others business that comes in the category of above mentioned activities. Table 3 shows that most of the respondents open their 'own shop' as their income generating 
activity and the second most prominent income generating activity started by respondents is 'stitching work'.

Table 2: Business started by Respondents after joining of SHGs

\begin{tabular}{|c|c|c|c|c|}
\hline & Frequency & Percent & Valid percent & Cumulative percent \\
\hline Yes & 398 & 98.5 & 98.5 & 98.5 \\
\hline No & 6 & 1.5 & 1.5 & 100.0 \\
\hline Total & 404 & 100.0 & 100.0 & \\
\hline
\end{tabular}

Table 3: Income Generating Activities started by Respondents after getting Amount of Loan

\begin{tabular}{|l|c|c|c|c|}
\hline & Frequency & Percent & $\begin{array}{c}\text { Valid } \\
\text { percent }\end{array}$ & $\begin{array}{c}\text { Cumulative } \\
\text { percent }\end{array}$ \\
\hline Embroidery work & 19 & 4.7 & 4.7 & 4.7 \\
\hline Dairy development & 71 & 17.6 & 17.6 & 22.3 \\
\hline Flower and bangle making & 39 & 9.7 & 9.7 & 31.9 \\
\hline Jute work & 38 & 9.4 & 9.4 & 41.3 \\
\hline Stitching work & 98 & 24.3 & 24.3 & 65.6 \\
\hline Vegetable cultivation & 16 & 4.0 & 4.0 & 69.6 \\
\hline Own shop & 123 & 28.0 & 28.8 & 97.5 \\
\hline Any other & 10 & 2.5 & 2.5 & 100.0 \\
\hline Total & 404 & 100.0 & 100.0 & \\
\hline
\end{tabular}

The analysis of financial literacy related aspects like ration card, own phone, Aadhar card, Voter ID card and account in bank shows that SHG members financial literacy has increased after joining of SHGs. The results of the study shown in Table 4 indicate that after joining of SHG, 96.5\% respondents are having ration card and only $3.5 \%$ are not having it; $79.3 \%$ respondents are having phone number and only $20.3 \%$ are not having it; $77.5 \%$ of the respondents are having voter ID card and only $22.5 \%$ are not having it; $43.1 \%$ respondents are having Aadhar card and $56.9 \%$ not having it; 331 $(81.9 \%)$ respondents are having accounts in banks and remaining $73(18.1 \%)$ are not having accounts in banks after joining of SHGs.

Table 5 shows the SHG members saving preference for their livelihood; the highest mean rank is 2.5545 , i.e. savings for husband's business and lowest mean rank is 1.6188 i.e. livelihood for own business. Lowest mean rank showed highest preference. 
Therefore, it is inferred that SHG member's first preferences for saving is their own business for their sustainable livelihood.

Table 4: Financial Literacy of SHGs Members

\begin{tabular}{|l|c|c|c|}
\hline Main variables & Sub categories of variables & Frequency & \% percentage \\
\hline Ration card & Yes & 390 & 96.5 \\
\hline & No & 14 & 3.5 \\
\hline Total & & 404 & 100.0 \\
\hline Own Phone & Yes & 322 & 79.7 \\
\hline & No & 82 & 20.3 \\
\hline Total & & 404 & 100.0 \\
\hline Voter Id & Yes & 313 & 77.5 \\
\hline & No & 91 & 22.5 \\
\hline Total & & 404 & 100.0 \\
\hline Aadhar Card & Yes & 174 & 43.1 \\
\hline & No & 230 & 56.9 \\
\hline Total & & 404 & 100.0 \\
\hline Account in bank & Yes & 331 & 81.9 \\
\hline & No & 73 & 18.1 \\
\hline Total & & 404 & \\
\hline
\end{tabular}

Table 5: SHG Members Saving Preferences for their Livelihood

\begin{tabular}{|l|c|c|c|c|c|}
\hline & $\mathbf{N}$ & Minimum & Maximum & Mean & Std. Deviation \\
\hline Own business & 404 & 1.00 & 3.00 & 1.6188 & 0.73091 \\
\hline Husband's business & 404 & 1.00 & 3.00 & 2.5545 & 0.65292 \\
\hline Loan repayment & 404 & 1.00 & 3.00 & 1.8218 & 0.78631 \\
\hline
\end{tabular}

Table 6 shows the SHG members saving preference for future security of their children. The highest mean rank is 2.2251 , i.e. saving for marriage of their children and lowest mean rank is 1.5817 , i.e., for education of their children. Lowest mean rank showed highest preference. Therefore, it is inferred that SHG members first preference for saving is 'education of their children' for future security after joining of SHGs. Table 7 shows SHG members saving preferences for their immediate expenditure. The highest mean rank is 2.7153 , i.e. saving for family clothes and lowest mean rank is 1.5718 for repairing of house. Lowest mean rank showed highest preference. So, it is inferred that 
SHG members first preference is 'repairing of house' from their savings after joining of SHGs.

Table 6: SHG Members Saving Preference for Future Security of their Children

\begin{tabular}{|l|c|c|c|c|c|}
\hline & $\mathbf{N}$ & Minimum & Maximum & Mean & Std. Deviation \\
\hline Education of children & 404 & 1.00 & 3.00 & 1.5817 & 0.76574 \\
\hline Marriage of children & 404 & 1.00 & 3.00 & 2.2252 & 0.70535 \\
\hline Business of children & 404 & 1.00 & 3.00 & 2.1856 & 0.80796 \\
\hline
\end{tabular}

Table: 7 SHG Members Saving Preference for Immediate Expenditure

\begin{tabular}{|l|c|c|c|c|c|}
\hline & $\mathbf{N}$ & Minimum & Maximum & Mean & Std. Deviation \\
\hline House repair & 404 & 1.00 & 3.00 & 1.5718 & 0.68104 \\
\hline Family clothes & 404 & 1.00 & 3.00 & 2.7153 & 0.52780 \\
\hline Diseases & 404 & 1.00 & 3.00 & 1.7054 & 0.69014 \\
\hline
\end{tabular}

\subsection{Conclusion}

The analysis of the primary survey shows that most of the respondents come in the category of 31-40 years age group and are married. Further, most of the respondents are living in nuclear families and are illiterate. The result of the study shows that maximum number of the respondents started their business by their amount of loan after joining of SHGs and are now doing different businesses for generating income and becoming empowered through their profits. SHG members' saving preferences for their livelihood is their own business development; SHG members' saving preferences for future of children is 'education of their children'; and SHG members' saving preference for immediate expenditure is 'repairing of house'. Regarding financial literacy of SHG members, result of study shows that financial literacy of the SHGs members have increased after joining of SHGs. The maximum number of respondents having ration card, phone number, voter id card, and their own account in bank have minimum knowledge about Aadhar card, even after joining of SHGs. Further analysis have shown that SHGs are becoming a tool that helps in starting income generating activities for SHG members and most of the members doing different businesses like 'zari' work, own shop, stitching work, flower and bangle making, open dairy, jute work, vegetable cultivation and some other works for their development, growth and empowerment. It is clear from the results that microfinance through SHGs has empowered women and has 
90 | MANTHAN: Journal of Commerce and Management, Volume 4, Issue 2, Jul-Dec 2017

improved saving habit among them. Saving preferences of members have changed after joining of the SHGs as they have now became aware that savings are essential for enhancement of their business, education of children, repairing of their houses and similar other needs.

\section{References}

Borah, A.(2014).Women empowerment through Self Help Groups-A case study of Barhampur development block in Nagaon district of Assam. IOSR Journal of Economics and Finance,4(3), 56-62.

Banerjee,P.,Sayed. V,\&Abraham, S.(2016). Self Help Group: A pathway towards credit and economic empowerment of women. International Journal of Advanced Research in Management, 7(1), 13-19.

Devi, K.U. \&Narasaiah.L,(2017). Women empowerment through self-help groups: An empirical study in Kurnool district of Andhra Pradesh. International Journal of Applied Research, 3(1), 101-105.

Henriques, E. J.(2016). Women empowerment: Analysis of the role of Self Help Groups in empowering rural women in Goa. MANTHAN: Journal of Commerce and Management, 3(2), 16-26.

Kumar, A. A. \&Kalva, U. K. (2014). Women's participation in economic development of India through Self Help Groups (SHGs). Journal of International Academic Research for Multidisciplinary, 2(5), 72-81.

Keshava,S. R.(2014).The changing dimensions of micro finance through SHGs in India: An analysis. Shiv Shakti International Journal in Multidisciplinary and Academic Research, 3(3), 130-145.

Kulshrestha, R..\& Gupta, A.(2001). Self Help Groups: Innovations in Financing the Poor, Kurukshetra, 49 (11), 26-29.

Kumar, S.(2012).Self- Help Group in socio-economic transformation with special reference to Coimbatore. International Journal of Research in Commerce, Economic and Management, 2(9),87-93. 
Lokahande,M.A. (2015).An empirical study of Self Help groups and awareness of group members. The International Journal-Research Journal of Commerce \& Behavioural Science, 4(12), 29-41.

Maurya, H. (2014).Impact of Microfinance on Poverty Eradication through SHGs: A case study of Pratapgarh District (Uttar Pradesh). International Journal of Science and Research(IJSR), 3(12), 10-14.

Mishra, K. C.(2017). Self Help Group: A strategy to rural development of Puri district in Odisha, India. PRAGATI: Journal of Indian Economy, 4(1), 1-22.

Narula, S.(2017).An examination into the link between financial inclusion, financial literacy and investment patterns. MANTHAN: Journal of Commerce and Management, 4 (1), 51-64.

Prakash, M.(2013).Self Help Groups and women empowerment with special reference to Jimmandiyur Village of PochampalliTaluk. .International Journal of Advanced Research in Management and Social Sciences, 2(3), 85-91.

Rai, K.(2015). Micro financing through SHGs empowering women: In Indian Context. International Journal of Management and Social Science Research Review, 1(8), 58-62.

Sarumathi, S. \& Mohan, K. (2011). Role of micro finance in women's empowerment (An empirical study in Pondicherry region rural SHG's).Journal of Management and Science, 1(1), 1-10.

Sharma, P. \&Varma. K. S.(2008). Women empowerment through entrepreneurial activities of Self Help Groups. Indian Research Journal Extension Education, 8(1), 4651.

Sandhu, G. K.(2013). A study of norms and functioning of Self Help Groups (SHGs) in Punjab. Journal of Business Management, 2(8), 1-6.

Singh, S. Ruivenkamp,G.\& Jongerden, J.(2011). A State of the art of Self Help Groups in India. Journal of Human Ecology, 36 (2), 91-102. 
92 MANTHAN: Journal of Commerce and Management, Volume 4, Issue 2, Jul-Dec 2017

Sharma, A.(2011). Women Empowerment: Milestone and Challenges. Kurukshetra, 59(11), 10-15.

Sharma, A. Roy, B,.\& Chakravorty, D.(2012). Potential of Self Help Groups as an entrepreneur: A case study from Uttar Dinajpur district of West Bengal. Journal of Social Science, 30 (1), 83-87.

Tehra, R. V.(2014).An Empirical Case Study of Women Self Help Group(SHG) functioning in Nanded City. Multi Disciplinary Education Global Quest, 3(4), 52-61. 